Journal of Qualitative Criminal Justice \& Criminology

\title{
Historical Book Review | On the Take: From Petty Crooks to Presidents
}

Gary W. Potter ${ }^{1}$

1Eastern Kentucky University

Published on: Oct 01, 2014

DOI: $10.21428 / 88 \mathrm{de} 04 \mathrm{a} 1.838 \mathrm{f} 58 \mathrm{fb}$

License: Creative Commons Attribution 4.0 International License (CC-BY 4.0). 
Bill Chambliss. On the Take: From Petty Crooks to Presidents. Indiana University Press, 1978/1988; 320 pp.; ISBN: 9780253202987.

\section{Organizing crime and qualitative research}

On the Take: From Petty Crooks to Presidents (first published in 1978) was the product of seven years (1962-1969) of observational research in Seattle, Washington (Chambliss, 1988). Chambliss used his background in law and sociology to interpret the things he saw and the stories he heard on Seattle's skid row. He gained entrée into Seattle's underworld by posing as an itinerant truck driver. Outfitted in old, worn shirts, khaki slacks and with bearded stubble on his face, he interacted with the bottom echelon of Seattle's crime entrepreneurs-bar owners, illegal card room and bingo operators, streetlevel drug dealers and prostitutes. His research demonstrated an important lesson for students of organized crime. Because organized crime relies on public participation of customers and players, it is often open, public, and easily accessible. As others have discovered, entrée is easily achieved, whether as an out of work truck driver, a gambler, a patron of deviant places, or even a casual customer. After several years at bottom of the organized crime pyramid, Chambliss gained introductions to businessmen, journalists, politicians and the police. At that level he discovered the real operatives controlling and directing illicit enterprise in American cities.

One of Chambliss' most important informants was a man with whom he made contact and built rapport early on in his research. "Bob Williams" was arrested at the age of 19 in one of Seattle's AfricanAmerican neighborhoods. He was beaten to death in jail while in police custody and that event set much of the tone for Chambliss' subsequent analysis. While Bob Williams was judged by the middleclass measuring rods of the criminal justice and system (and criminologists), he was, in fact, a highly sophisticated, street smart drug dealer. He operated in what he referred to as the jungle, buying drugs in quantity at reduced prices and selling them for a large profit to individual users. He was in every way a lone wolf in Seattle's highly organized drug underground: "I'm an independent. Some of these guys have all kinds of strings on 'em. Not me, man. I'm my own boss. Ain't nobody gonna pull me around by the nose" (p. 50). At the time of his arrest, Williams had $\$ 1500$ worth of heroin in his possession. The heroin disappeared while in police custody.

The patrol officer who arrested Williams told Chambliss that he had called them names and tried to jump out of the patrol car. Williams was arrested at 8 p.m. and was taken to the emergency room at midnight badly beaten and unconscious. The next day he was released back into police custody a little after noon. Later that afternoon Williams was returned to the hospital with a concussion. He died at 3 a.m. from a brain hemorrhage. The official police report said he had been beaten by his fellow inmates. The corner decided that the death was accidental (p. 51). 
Bob Williams was cannon fodder in the war on drugs. The informant who had told the police where to arrest Williams and that Williams was running dirty was generously paid with confiscated heroin. The Williams case points to an enduring truth about both law enforcement and the drug market. Small, independent dealers not connected to larger crime networks provide the police with easy arrests. They also disguise the far more profitable and pervasive politically connected drug traffickers who dominate the street market. The logic of this is simple. The profits of the large drug networks are substantial and fuel both corruption and the city's economy. The small incomes of independent operatives are expendable.

It is somewhat ironic that on the night Williams was beaten to death, Chambliss was playing in a highstakes poker game with a senior vice squad police officer.

Drug trafficking was only one of the myriad illegal enterprises operating openly in Seattle. While it may seem odd today, both bingo and pinball were illegal unless licensed by the state in the early 1960s. In Seattle, eleven bingo parlors were operating. The largest of the bingo parlors was realizing profits of $\$ 240,000$ a year after paying all its expenses including bribes to police and politicians. There were 3,500 licensed pinball machines in the state of Washington grossing over $\$ 7$ million a year. The cost of licensing and maintaining the machines was tiny and the taxes were almost nonexistent, because in a cash business virtually all profits could be hidden and laundered. In Seattle there was one master license for all the pinball machines. It gave one crime network access to all amusement arcades, restaurants, and bars in the city. That crime network was run a small group of legitimate businesspeople who were closely tied to the city's political establishment. And, despite the fact that gambling was illegal in Washington by 1968 Seattle had the highest number of federal gambling stamps of any city in the United States except Las Vegas.

High-stakes poker games occurred every night in dozens of locations throughout the city with total buy-ins that often exceeded $\$ 100,000$. Every day of the year, except for Christmas, the people who ran those games took $10 \%$ of every pot on every table.

As in other cities, loansharks were usually legitimate businessmen-pawn brokers, jewelers, and discount merchants. They made small loans for very high interest rates, typically $\$ 6$ dollars repaid for every $\$ 5$ borrowed each week. Larger loans were a little more lenient. Chambliss provides an account of one Seattle jeweler who loaned a customer $\$ 220,000$ with the understanding that loan would be repaid at $\$ 350,000$ in thirty days. The total profits from gambling drugs, usury and the fencing of stolen goods exceeded $\$ 100$ million a year in Seattle; organized crime was the city's second largest industry.

Business, whether licit or illicit, requires investment capital. It also requires regulation and protection in order to maximize profits. Legal businesses are dependent on a system of law to protect property 
and enforce contracts. Illicit enterprises have no such protection. A bookmaker cannot sue over a gambling debt. A pusher cannot seek legal redress if his or her wholesaler supplies inferior merchandise with low levels of purity. But predictability and regulation are as important for illicit entrepreneurs as they are for banks and retail outlets. Without those protections, the risk to initial capital investments would be too great to attract financing. So how are illicit markets regulated? As Chambliss points out, the answer is really quite simple. Illicit entrepreneurs must seek out partners who would otherwise be charged with enforcing the laws against them. In Seattle politicians, lawenforcement officials, lawyers, bankers, accountants and legitimate businessmen became willing partners in illicit enterprise (p. 53).

The police were paid off, and the profits were such a large part of the city's economy that there was no political pressure for enforcement of the laws. In Seattle, a bagman collected the pre-arranged payoff from every gambling operator. Those who operated illegal card rooms reported paying about $\$ 300 \mathrm{a}$ month each to the police.

With some irony, Chambliss chose the pseudonym Fred Lindesmith for one of his informants. As a police officer, Lindesmith had actively participated in the system of payoffs and retired with substantial financial security. He described who got paid in detail: "Everyone. The beat cop, the vicesquad captain, the prosecutor. Everyone. It depended on the gig. Narcotics payoffs went through the vice squad and the patrol division. Sooner or later it all went up to the top" (p. 56). Separate payoff systems operated for the burglary and narcotics squads, and burglary payoffs were as lucrative as gambling payoffs. In narcotics, a combination of rip-offs and the subsequent resale of drugs to dealers and bribes from dealers resulted in thousands of dollars for a single payoff. The arrest and subsequent death of Bob Williams was directly related to one of these rip-offs.

Tavern owners were involved in a second line of bribes that enabled them to obtain liquor licenses, illegal alcohol, alcohol stolen from state warehouses, and watered-down alcohol. That money went directly to state officials including the Governor's office and members of the state legislature, for the bagman for these payoffs was a member of the state legislature.

In a way, the payoff system could be viewed as an informal system of taxation that provided order and stability to the illicit market place. But, as Chambliss discovered, the flow of illicit capital was far more complex. In essence it defined and greatly impacted the political economy of Seattle itself.

Chambliss calculated that there were well over 1,000 people who directly profited from organized crime in Seattle. Illegal enterprises which were highly regulated and highly profitable entailed highly systematized profitsharing schemes. While the actual purveyors of vice were a diverse group of independent operators, the system which enabled and protected their enterprises was highly structured. 
Participation in illicit markets was dispersed across all ethnic, racial, and class lines in Seattle. It involved a panoply of individuals which changed constantly, with entrepreneurs coming in, leaving, and often re-entering illegal markets. But beyond this kaleidoscope of dealers, gamblers, fraudsters, and loansharks was an informal system of control dictated by power. As Chambliss pointed out, issues arise, crises occur, and problems must be resolved. Therefore some people had greater power to make critical and crucial decisions than others; those who profited most from organized crime were also those who had the power to make those decisions.

In Seattle those power-brokers included a county prosecutor, the county sheriff, the city council president, an assistant chief of police, police captains, the president of the Amusement Association of Washington, and a high-ranking official of the Teamsters Union. Right below these decision-makers were members of the business and professional communities who influenced the decisions to be made and profited from those decisions. They included a defense attorney for many illicit entrepreneurs, a major realtor, an officer of the city's largest bank, and a board member of a large financial services company.

Chambliss provides numerous examples of how this system of regulation worked. But the most telling and detailed involves a dispute over pinball operations in Seattle. In the mid-1960s "Bill Bennett" made a move to enter into pinball business. Bennett's brother, "Frank" was already a major illicit entrepreneur in the sex trade running a large prostitution operation. Initially, Bill Bennett asked for a share of the pinball action. But his initial overture was resisted. Pinball machines were under the control of several individuals already and the master license for the county was held by the Amusement Association. The president of the Amusement Association oversaw operations in the county and handled payoffs to politicians and the police department. He collected a monthly fee from all pinball operators to cover the payoffs.

A political split between the country prosecutor, who was allied with the Amusement Association, and several other politicians gave Bennett an opening. He and several individuals working with him firebombed a number of establishments operating pinball machines and a few restaurant and bar owners were the recipients of beatings. This created an intolerable situation because the local press was beginning to take notice of the violence. In order to calm the situation down, the pinball operators offered to let Bill Bennett into the racket if he paid them a $\$ 20,000$ entry fee and a $\$ 2$ a month surcharge on each machine he operated. But the arrangement was not acceptable to the police. The chief of police saw Bill Bennett as a dangerous, violent, and difficult to control hood. The police chief went even further in his opposition to the deal, insisting that Bill Bennett leave the city altogether. Confronting other gangsters was one thing, but animosity from the police was more than Bennett could take, and he left Seattle. 
This little vignette is important because it reveals several things about the organizing of crime. First, there is competition for illicit profits among illicit entrepreneurs. Second, power is not evenly distributed in the underworld, even in the face of violence. And finally, it demonstrates what other research has also found in many other cities; it is the police who often organize crime (Potter and Jenkins, 1985).

As his research concluded, Chambliss explored the question of organization in Seattle's underworld. Was it the tight, ethnically determined hierarchy popularized by federal law enforcement or something entirely different? He got a direct answer. One professional thief who also had a hand in gambling, prostitution and drugs told him: "You can forget that Mafia stuff. We are Hoosiers out here." Everyone he talked to expressed a similar view. One informant was particularly direct:

Every time you check the Congressional Record and you see the FBI diagramming the Mafia families in San Francisco, you can tell them to shove it up their ass, because you can't diagram this. If you do diagram it, you can't read your diagram when you're done. It's all squiggly lines: the chain of command and who's in charge of any operation and who's entitled to what cut of the graft, it's all very changeable. (p. 67)

After he was told by numerous people he played poker with to go a particular café on the second Thursday of every month and take note of who met there for lunch, Chambliss made twelve visits to the rendezvous site and noted a regular gathering of the assistant chief of police, an assistant prosecutor, an undersheriff, and a local criminal attorney. On and off, this group was supplemented by a local contractor, the representative of an investment firm, the president of the Amusement Association, a hotel owner, a member of the city council, a member of the country board of supervisors, and a Teamsters Union officer.

So it was not the purveyors of vice who were getting rich from organized crime, it was the businessmen with the investment capital necessary to expand high-profit illicit enterprises and the police and politicians who could sell their power. Seattle had no Godfather and no criminal hierarchy. It had a network of businessmen, politicians, police officials, and illicit entrepreneurs who protected vice, kept the peace, and ensured the safety of their investments. The descriptions of each of the major players in this crime network that Chambliss portrayed were fascinating, although too detailed to go into in this brief article, but can serve as a template for all the other field research done in different cities (Albini, 1971; Ianni \& Ianni, 1972; Potter, 1994; Potter \& Jenkins, 1985).

On the Take concludes with several chapters relying on historical research what trace the role of corruption in American society from Lincoln Steffens to Richard Nixon. Chambliss outlines the organized connections of national political figures and discusses specific well-known cases of corrupt behavior. One of the more important propositions put forth by Chambliss was an idea he and Alan 
Block elaborated on in Organizing Crime (Block \& Chambliss, 1981). Chambliss suggests that there were major political differences within organized crime, particularly relating to drug trafficking in the 1960s. He describes Meyer Lansky, a major illicit financier, as being closely aligned with the conservative wing of the Democratic Party, particularly with figures like Mayor Richard Daly of Chicago and Governor John Connelly of Texas. He also alleges that other prominent organized crime figures including Santo Trafficante, Jr. were closely connected to Richard Nixon, primarily through Florida businessman Bebe Rebozo. The importance of this is that according to Chambliss, the Vietnam War's prosecution under Nixon shifted the U.S. heroin market from one that was dependent on Lebanese heroin moving through Marseilles to Southeast Asian heroin moving from the Golden Triangle through South Vietnam and Taiwan. Chambliss sees this as an attack on Lansky by Nixon. That theme was elaborated on in great detail a few years later by Dutch journalist Henrik Kruger in his book The Great Heroin Coup (Kruger, 1980). Other researchers have also subsequently developed strong evidence linking Richard Nixon to organized crime and Lansky to big city political machines (Block \& Chambliss, 1981; Lyman \& Potter, 2014; Simon, 2012).

Chambliss makes the case that political corruption is openly peddled in a corruption market in the United States. In the concluding Chapter 8, "The Enemy is Us," he engages in a detailed discussion of criminal law, its inherent class-bias, and its protection of property rights, all of which he links to the massive markets for illicit goods and services in the United States. He goes even further linking a system of bourgeois democracy to organized crime:

Crime networks with access to billions of dollars in untaxed, unreported, and unaccountable funds are a valuable source of money to oil capitalism's political machinery...Through it all the crime network becomes an institutionalized, fixed, and permanent link in the chain of a nation's political economy. That is what has happened in America. That is why crime networks persist year after year with only the faces and methods of operation changing (p. 210).

The importance of On the Take cannot be overstated. First, it challenges the state and media view of organized crime. Others like Joe Albini (1981), Alan Block (1979) and Dwight Smith (1978) raised major concerns over the historical record, but it was Chambliss who went to the streets to articulate the dayto-day workings of crime networks. The description of organized crime as a social network was criminological heresy following Donald Cressey's publication of The Theft of the Nation (Cressey, 2008). Despite the fact that a tightly organized, bureaucratic hierarchy run by only by men of Italian descent seemed illogical on its face, it was the hegemonic doctrine of both state police and criminological discourse. The Mafia myth was essential. Organized crime serves hundreds of millions of customers a day in the open in every city in the United States. Organized crime was a major sector of the

U.S. economy. This had to be explained, and there were very limited alternatives for those explanations. The first was easy, considering American's historical fascination with foreign 
conspiracies. Organized crime was a cleverly constructed, sinister, hierarchical conspiracy that could not be controlled without new draconian laws and additional law enforcement funding. It was a conspiracy of foreign immigrants attacking the very souls of the righteous, God-fearing American people. Or, law enforcement was totally incompetent and could not see what drug addicts, gamblers, johns, and fraudsters could easily access every day. Or, the whole system was thoroughly corrupt and dependent on the very crimes it outlaws for profit and investment capital.

Chambliss and the rest of us who challenged this notion were attacked in the journals and in the press. But by the early 1990s, the myth of the Mafia had been replaced in almost every criminology textbook and journal article on organized crime by the reality of crime networks (Williams, 2002; Woodiwiss, 2001). Italian sociologist Letizia Paoli (2002) said it best when she concluded that hierarchical crime structures were extinct dinosaurs if they had ever existed at all. The notion of a crime network implicates the state, politicians, law enforcement and legitimate businessmen in the maintenance of illicit markets. That was a truly revolutionary notion.

Second, Chambliss demonstrates that qualitative research on the streets could be successfully used to study extremely complex social relations. Prior to On the Take, qualitative methods were predominantly used to look at micro issues in small environments such as nude beaches, the tea room trade, and employee pilferage. Studying organized crime required that criminologists rely on the state for data. Cressey was given exclusive access to state documents, informants, and wiretaps, but the data had been culled and selected by federal law enforcement agencies. The dangers of this are obvious. First, government agencies will present their point of view in any self-produced documents. That means that evidentiary contradictions, interpretations of events that differ from their own, and conflicting information have been carefully edited out. Second, for a variety of reasons, many of which have to do with budget allocations and legal powers, official agencies tend toward conspiratorial accounts of criminal enterprise - this is quite logical from their point of view. Presenting organized crime and drug dealers as a group of disorganized entrepreneurs would scarcely lead to more money, more personnel, and greater legal powers. In fairness, Cressey published a research note warning that his research in Theft of the Nation had validity, reliability, and ethical problems (Albini, 1988). Of course, the difficulty is that the research note was read by only a few hundred academics while the book was read by millions.

Third, Chambliss lays out a road map for large-scale qualitative research on extremely complex and intricate issues. He demonstrates that the argument that it was not possible to gain entrée into criminal groups was wrong. Crime networks operate in public places, on regular schedule and serve millions of clients out in the open. Posing as an out-of-work, scruffy, itinerant truck driver was a means of easy entrée which had no impact on the social setting being observed. Bill Chambliss was an engaging, gregarious, imposing individual and a consummate conversationalist. It is easy to see how he 
made his research role work in the real world. Others have done similar things. Ianni used neighborhood friendships and acquaintances to access the "Lupollo family" (Ianni \& Ianni, 1971). I have posed as a gambler (not really much of stretch) (Potter, 1994; Potter \& Jenkins, 1985). Once researchers understand that every entrepreneur in illicit markets goes to bars and taverns and frequent poker games (where the money is), developing useful contacts is easy.

Of course, Chambliss' research also highlights the problems with this kind of large-scale research. The street work for On the Take lasted seven years. My field work for Criminal Organizations (1994) took five years. Under the restrictive rules of academia, that is a tenure-seeking lifetime. But with our obsession with quick and dirty analyses of extant databases, we have lost the real meaning of crime and the social interaction which underlies it. John Lea frequently researches social crime (Lea, 2002). The problem with contemporary criminology is that our methods of analysis do not allow us to understand the social aspect. Organized crime can only be understood by following the advice of Robert Park and Howard Becker by getting out of the libraries, off our computers, out of SPSS and back on the streets, getting the seats of pants dirty (Becker, 1998; Park, 1915).

Chambliss also understood the criticisms of qualitative research with regard to validity and reliability. After all, this is one researcher's interpretation of events he or she sees and experiences. In addition, even if accurate it is a description of a single place or event or time and therefore not generalizable. On the Take helps to put to rest many of these concerns. It began a series of qualitative and historical case studies of criminal organization in Seattle, New York, Philadelphia, Detroit, Scranton, the rural counties of Eastern Kentucky and many more places including Sicily itself (Albini, 1971; Block \& Chambliss, 1981; Potter, 1985; Potter \& Gaines, 1992; Potter \& Jenkins, 1985). The dozens of studies of specific places and specific enterprises created a database from which the generalizable emerged. And the conclusion from all of those dozens of studies is that Chambliss got it right. But the ultimate validation is that almost all of these studies came when investigators finally arrived. In Seattle, virtually every public figure alluded to in Chambliss' research was indicted, convicted, and imprisoned. It took years but it happened. We have all felt the same vindication.

On the Take is a criminological classic. It is a masterpiece that shows us how to do qualitative research, how to theorize from that research, and how to tell a compelling story about crime. It is a shining example of why crime needs to be understood not merely described.

On the Take reads like great research written like a crime noir novel in the tradition of Big Jim Thompson or Dashell Hammet. As such, it is a classic criminological work. But it is only one of the monumental contributions to the discipline by Bill Chambliss. Chambliss wrote 22 books and countless journal articles during his career. He strengthened qualitative research with his outstanding research on juveniles in "The Saints and the Roughnecks" (1973); professional theft in Boxman: A Professional 
Thief's Journey (1972); and policing the drug war in "Policing the Ghetto Underclass: The Politics of Law and Law Enforcement" (1994).

Chambliss also undertook the most authoritative and complete analyses of the role of criminal law in the United States and capitalist societies in general when he and Seidman wrote Law, Order and Power (1971); he and Zatz were responsible for Making Law: The State and Structural Contradictions (1994); and Chambliss continued writing on the political scene in Power, Politics and Crime (2001).

Bill Chambliss was a riveting speaker and writer. He was also a great mentor and friend. As a graduate student I had the privilege of working with Bill, Gil Geis, Alan Block, and Phil Jenkins at Penn State. They were all generous and accomplished scholars who guided my studies and my research. They were all demanding taskmasters. Chambliss and Geis were visiting professors during my studies. Gil taught me how to write, question, and challenge criminological orthodoxy, especially social control theory. Billy critiqued my work, reviewed my field notes, made me toe the line in my methods section (although this is something he rarely did) and expanded my thinking from the mechanics of crime to the mechanics of crime in capitalism. He was a generous and brilliant mentor. I can safely say that after 26 years of research and writing I never had an "original” idea that Bill Chambliss didn't have first.

\section{References}

Albini, J. (1971). The American mafia: Genesis of a legend. New York, NY: Appleton-Century-Crofts.

Albini, J. (1988). Donald Cressey's contributions to the study of organized crime: An evaluation. Crime and Delinquency, 34, 338-354.

Block A. (1979). The snowman cometh: Coke in progressive New York. Criminology, 17, 75-99.

Block, A. (1974). The mafia of a Sicilian village, 1860-1960: A Study of violent peasant entrepreneurs. New York, NY: Harper \& Row.

Block, A. \& Chambliss, W. (1981). Organizing crime. New York, NY: Elsevier.

Becker, H. (1998). Tricks of the trade: How to think about your research while you're doing it. Chicago, IL: University of Chicago Press.

Chambliss, W. (1972). Boxman: A professional thief's journey (with Harry King). New York, NY: Harper \& Row.

Chambliss, W. (1973). The saints and the roughnecks. Society, Nov/Dec, 2431. 
Chambliss, W. (1988). On the take: From petty crooks to presidents (2nd ed). Bloomington, IN: Indiana University Press.

Chambliss, W. (1994). Policing the ghetto underclass: The politics of law and law enforcement. Social Problems, 41(4), 177-194.

Chambliss, W. (2001). Power, politics, and crime. Boulder, CO: Westview Press.

Chambliss, W. \& Seidman, R. (1971). Law, order, and power. Boston, MA: Addison-Wesley Publishing. Chambliss, W. \& Zatz, M. (Eds.). (1994). Making law: The law, state and structural contradictions. Bloomington, IN: Indiana University Press.

Cressey, D. (2008). Theft of the nation: The structure and operations of organized crime in America. New York, NY: Transaction Publishers.

Ianni, F. \& Reuss-Ianni, E. (1972). A family business: Kinship and social control in organized crime. New York, NY: Russell Sage Foundation.

Kruger, H. (1980). The great heroin coup: Drugs, intelligence, \& international fascism. Boston, MA: Southend Press.

Lea, J. (2002). Crime and modernity: Continuities in left realist criminology. London, England: Sage.

Lyman, M. \& Potter, P. (2014). Organized crime (4th ed). Englewood Cliffs, NJ: Pearson.

Paoli, L. (2002). The paradoxes of organized crime. Crime, Law and Social Change, 37, 51-97.

Park, R. (1915). The city: Suggestions for the investigation of behavior in the city environment. American Journal of Sociology, 20, 579-583.

Potter, G. (1994). Criminal organizations: Vice, racketeering, and politics in an American city. Prospect Heights, IL: Waveland Press.

Potter, G. \& Gaines, L. (1992). Country comfort: Vice and corruption in rural settings. Journal of Contemporary Criminal Justice, 8, 36-61.

Potter, G. \& Jenkins, P. (1985). The city and the syndicate: Organizing crime in Philadelphia. Lexington, MA: Ginn Press.

Simon, D. (2012). Elite deviance (10th ed). Englewood Cliffs, NJ: Pearson. 
Smith, D. (1978). Organized crime and entrepreneurship. International Journal of Criminology and Penology, 6, 161-177.

Williams, P. (2002). Cooperation among criminal organizations. In M. Berdal \& M. Serrano (Eds.), Transnational Organized Crime and International Security (pp. 67-80). Boulder, CO: Lynne Rienner.

Woodiwiss, M. (2001). Organized crime and American power. Toronto, ON, Canada: University of Toronto Press. 